\title{
【研究報告】
}

市街地復興都市計画策定のための地方公共団体のデー夕整備の要件

寺木 彰浩、渡邉一成

\section{Requirements for Urban Restoration Planning to Basic Data in Local Authorities}

\author{
Akihiro TERAKI and Kazunari WATANABE
}

\begin{abstract}
This paper deals with requirements of data for choosing locations for projects and regulations under a restoration plan. Basic data for choosing locations are compared data provided by the Urban Planning Basic Survey defined by Ministry of Construction. The results show that the Urban Planning Basic Survey provides most of data required by a restoration plan. The results, however, show that it is difficult to apply those data directly to planning processes.
\end{abstract}

Keywords: 地方公共団体 (Local authority)、都市計画基礎調査 (Urban Planning Basic Survey)、市街地 復興都市計画（Urban Restoration Planning）

\section{1. はじめに}

兵庫県南部地震は広範な市街地に甚大な被害をも たらしたため、被災した地方公共団体では広域にわ たって各種の被害状況を的確に収集・分析するとと もに、速やかに復旧・復興計画を立案することが求 められた。その際に地理情報システム（Geographic Information System: GIS）の活用が、復旧・復興計画 の迅速な検討・立案に資するとの提言や、その有用 性を実際に示す具体的研究がなされてきた（寺木ほ か, 1995 ; 山崎, 1996 ; 岩井ほか，1996）。これを 契機として、地方公共団体などでは都市計画を始め とした様々な業務へのGISの導入が検討されつつあ る。したがって、その足場となる基礎的なデータが どうあるべきかについての検討は急務であるといえ よう。

寺木 : $\overline{7} 305$ 茨城県つくば市立原 1 建設省建築研究所第六研究部都市開発研究室 Tel. 0298-64-6698 Fax. 0298-64-6771 Urban Development Div., Urban Planning Dept., Building Research Institute, Min. of Construction. 1 Tachihara, Tsukuba, Ibaraki 305 Email: teraki@kenken.go.jp
本研究は、地方公共団体が整備する基礎的データ がGISによって実際の業務に活用されるための要件 について検討するものである。具体的には、阪神淡 路大震災後の市街地復興都市計画を取り上げ、都市 計画基礎調査によって得られるデータが計画策定と いう目的を満たしうるかどうか、比較する。以下、 第 2 章では地方公共団体においてGISが活用される ための要件について論ずる。第 3 章では市街地復興 都市計画の策定に際して必要となるデータについて 整理し、第 4 章で都市計画基礎調査によって得られ るデータとの比較を行う。

\section{2. 地方公共団体におけるGIS活用の要件}

わが国においては、様々な機関がGISの拠所とな る基礎データを作成し、管理・更新を行っている。 中でも、地方公共団体が所持する、地域に関する詳 細な情報の重要性は極めて高く、その活用に対する 期待は大きい。これまでも地方公共団体へのGISの 導入は様々な形で行なわれており（玉川，1996）、 GIS学会においても自治体SIGによる積極的支援が行 なわれているが（田中ほか，1995）、未だ十分に普 
及しているとはいえない。

GISの地方公共団体への普及を疎外する要因とし ては、「どこにデータがあるのか分からない」、「類 似したデータが複数あって、どれを使えばよいか分 からない、「どのようにGISを使えば求める情報が 得られるのか分からないなど、具体的な業務に則 したGISの利用についてのノウハウの蓄積が不十分 であるため、活用のイメージが湧かず、導入必要性 の説得力が弱いことが挙げられる。

データベース利用に当たってのノウハウ蓄積の難 しさについては、GISの場合に留まらず、情報の活 用を指向したシステム全般について従来から指摘さ れているところであり、既に、利用者と情報の保管 場所とをネットワークで結び付け効率的な情報活用 を図る仕組である「クリアリングハウス」や、情報の 在処や内容・精度について記述する、情報について の情報「メタデータ」、具体的な利用目的に即して情 報を蓄積していく「データウェアハウス」といった新 しい概念が提唱されている。

この流れを踏まえて、1995年 8 月に建設省が設置 したGIS研究会においても、GISにおける「クリアリ ングハウス」、「メタデータ」の重要性が指摘されて いる゙1。また「メタデータ」についてはGIS利用のた めの標準的な規格についてISOで国際的な検討が進 められているところである2)。しかし、これらはい ずれもデータの共有化を指向した試みであり、具体 的な業務におけるGISの活用という視点に欠けてい るため、前述のGIS普及の疎外要因に直接応えるも のとはなり得ない。したがって、利用目的を絞りこ んで、GIS活用のための要件を検討する必要があ る。

以下、例として阪神淡路大震災に対する市街地復 興都市計画を取り上げ、GISを活用して計画と関連 事業を検討する際に必要なデータの整理を通じて、 データウェアハウスとして地方公共団体が機能する ための要件について検討を行う。

\section{3 市街地復興都市計画で必要となるデータ}

3.1. 対象となる規制、事業の抽出 市街地復興都市計画を検討・立案していく場合に
は、計画の中で具体的に検討することが要求される 個別の規制、事業について、適切な対象地域を選定 していく事が必要である。例えば神戸市において は、震災直後に建築活動を制限した後、具体的な規 制と投入すべき事業について検討している。その際 には、関係者間の調整のための資料の提供や情報公 開などを考慮し、可能な限り定量的なデー夕に基づ く客観性を担保しながら、迅速に検討を行うことが 要求される。

このような作業にGISを活用することを考えた場 合、最も効果が期待できるのは、各々の規制、事業 を投入するための適地を選定する作業の支援であ る。すなわち、市街地復興都市計画策定という目的 に対して地方公共団体がデータウェアハウウスとして 有効に機能するためには、関連する規制・事業の適 地選定のために必要な基礎的なデータを効果的に提 供することが求められる。

本稿では、市街地復興都市計画に関連して以下の 規制・事業を取り上げ、それぞれの適用要件から、 GISを活用した適地選定に必要となる基礎データに ついて整理する。

（1）建築物に関する規制

・建築基準法84条に基づく建築制限

- 震災復興緊急整備条例（神戸市）による「災害 復興促進地域」「「重点復興地域」

・被災市街地復興特別法に基づく「被災市街地復 興推進地区」

（2）投入すべき事業

1）面的な性格を持つもの

(a)主な目的が基盤施設の整備にある事業

- 区画整理事業

・被災市街地復興土地区画整理事業

(b)主な目的が建築物の整備にある事業

・都市防災不燃化促進事業

・密集住宅市街地整備促進事業

・住宅市街地総合整備事業

2）単体としての建築物を対象とするもの

- 第 1 種市街地再開発事業

・優良建築物等整備事業 


\section{2. 必要となるデータの抽出}

表 1 に市街地復興都市計画における主な規制・事 業とその適地を選定するために必要となるデータに ついて整理した。

基礎データは、「前提となる規制・計画」、「地区 現況（数値指標によって評価しうるもの）小、「地区 現況（文言によって記述されているもの）」に類型 化された。

この中で注目すべき点は、市街地の現況を物理的 に示す指標と並んで、他の規制や事業による地域指 定を既に受けていることが、適地選定の要件として 数多く挙げられていることである。

「各地域の復興の必要性の 1 部については、より 上位の、あるいは、より基本的な計画・規制・事業 の中で既に検討されており、オーソライズされてい るはずである」という考え方が示されている。また 地区の現況については、GISの活用になじみやすい 「数値による評価」と、なじみにくい「文言による評 価があり、今後、後者へのGISの活用が検討される 必要がある。

次に表 1 で示された基礎データについて各類型の 中で整理を行った（表 2）。「前提となる規制・計 画」については「国土開発に関する計画」、「土地利 用に関する計画」、「建設省による事業制度」、「地方 公共団体が制定した条例及び計画」に大別すること ができる。これにより以下の（1）〜（3）が指摘 できる。

（1）復興計画にかかる規制・計画の体系が、対象 地区選定の要件の上で表されている。

（2）既存の規制・事業に関する空間データを整備 することにより、より下位の、あるいは、より即 地的な、従って、より検討の機会の多い規制、事 業の企画、立案の効率化を図ることができる。

（3）上位の、あるいは、基本的な規制・事業の検 討に必要な基礎データの整備と効果的な活用によ り、復興計画にかかる規制・事業の全体的な底上 げを期待できる。

また「地区の現況（数值指標によって評価しうる もの）」においては、地区面積、建築面積といっ た、地区や建築物の基本的諸元が、多くの規制・事
業の要件となっていることが示された。また、当然 のことながら、被災状況の迅速な把握も求められて いる。

「地区現況（文言によって記述されているもの）」 においては、平常時、災害時のそれぞれについて、 「地区現況」、「政策判断」、「将来像」に大別される が、その中でも、（1）数值指標によって評価しう ると考えられるが、「十分な」、「相当数の」など表現 によって判断基準が瞹昧であるもの、（2）「必要 とする」、「見込まれる」など、数值指標に馿染みに くい表現によって記述されているもの、がある。

\section{4. 利用可能なデータとの比較}

前章では市街地復興都市計画を検討する際に必要 となる基礎的なデータについて検討したが、本章で は実際に地方公共団体において利用が可能である データについて検討を行う。

\section{1. 都市計画基礎調查}

地方公共団体では市街地復興都市計画に関連する 多様なデータを有している。しかし、いずれのデー タについても固有の目的に対して最大限の効率が得 られるように整備されており、目的外の使用に対し ての利用は制度上も技術上も難しいことが多い。し たがって、本稿で扱っている大規模災害後の市街地 復興都市計画の策定のように、極めて限定された期 間内で、混乱した状況下での検討が要求される場合 には、平常時からの必要となるデータの蓄積を行っ ておくことが求められる。

都市計画の決定、変更等を行うための資料として は、都市計画法第 6 条第 1 項に基づいて、地方公共 団体は都市計画に関する基礎調查を概ね 5 年毎に行 うこととなっている。調査項目については、昭和 62 年に建設省都市局都市計画課によって作成された

「都市計画基礎調查実施要領」（以下、「要領」と略 称する）によって目安が示されているが、「1.人 ロ1、「2.産業」、「3.住宅」、「4.土地利用及び土地利 用条件」、「5.建物」、「6.都市の歴史と景観」、「7.都 市の緑とオープンスペース」、「8.地価」「9.都市施 設」「10.交通」の大項目が掲げられている。 
表 1 市街地復興計画における主な規制・事業とその適地選定上で必要となる基礎データ

\begin{tabular}{|c|c|c|c|c|c|c|}
\hline \multirow{2}{*}{\multicolumn{4}{|c|}{ 市街地復興計画における主な規制・事業 }} & \multicolumn{3}{|c|}{ 必要となる基碮データ } \\
\hline & & & & 前提上なる規制・計画 & 地区現況 (数値) & 地区現況 (文言) \\
\hline \multirow{4}{*}{ 規 } & \multirow{3}{*}{\multicolumn{2}{|c|}{\begin{tabular}{|l} 
建築基隻法 \\
震災復興緊急整備 \\
条例 (神戸市) \\
\end{tabular}}} & 84 条区域 & 竞地区(市街地再開発方針) & 被災状況 & \\
\hline & & & 災害復興促進区域 & 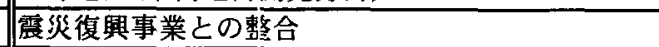 & 被災状況 & \\
\hline & & & 重点復興地域 & 災害復興促進区域、 1 号市街地（市街地再開発方針） & 被災状況 & 良好な市街地への再生が必要な地区 \\
\hline & \multicolumn{2}{|c|}{$\begin{array}{l}\text { 被災市街地復興 } \\
\text { 特別措置法 }\end{array}$} & $\begin{array}{l}\text { 被多市街地復興 } \\
\text { 推進地域 }\end{array}$ & |都市計画区域 & & 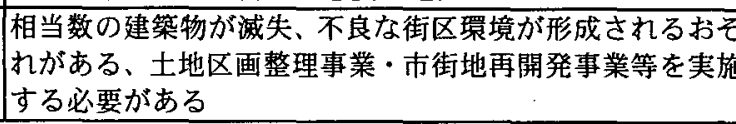 \\
\hline \multirow{7}{*}{\multicolumn{2}{|c|}{$\mid \begin{array}{l}\text { 面 } \\
\text { 的 } \\
\text { 整 } \\
\text { 備 }\end{array}$}} & \multirow[b]{2}{*}{$\begin{array}{l}\text { 土地区画 } \\
\text { 整理事業 }\end{array}$} & |組合等による施行 & $\begin{array}{l}\text { 都市計画区域、都市計画道路の新設又は改築を含む } \\
\end{array}$ & & $\begin{array}{l}\text { 公共施設の整備改善を必要とする区域、宅地の利用增進を } \\
\text { 必要とする域 }\end{array}$ \\
\hline & & & 公共団体等による施行 & \begin{tabular}{|l} 
|都市計画区域、都市計画道路の新設又は改筑を含む \\
|地区
\end{tabular} & & 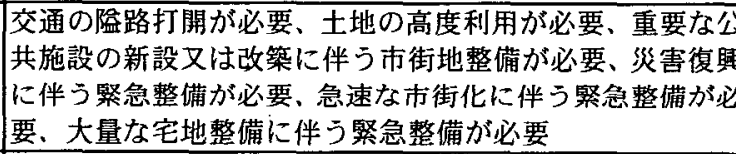 \\
\hline & & 被災市街地行 & 復興土地区画整理事業 & $\begin{array}{l}\text { 被災市街地復興推進地域、都市計画決定済の幹線道 } \\
\text { 路を含まないい }\end{array}$ & $\begin{array}{l}\text { 被災地の面積が概ね20ha以上 } \\
\text { 被災戸数が概ね2000戸上上 }\end{array}$ & \\
\hline & & \multicolumn{2}{|c|}{ 都市防災不撚化促進事業 } & 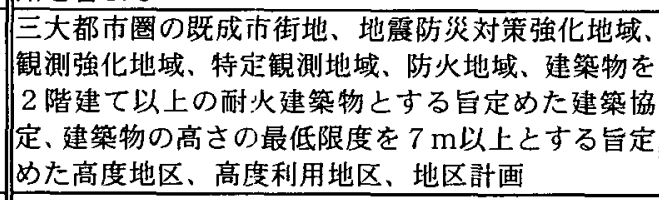 & & 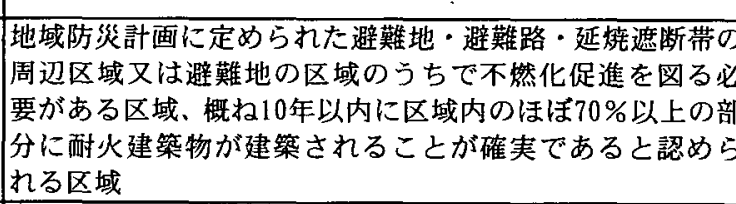 \\
\hline & & \multirow{2}{*}{\begin{tabular}{|l} 
密集住宅 \\
街地整備 \\
促進事業
\end{tabular}} & 一般型地区 & 三大都市圈における近郊整備地帯・都市開発区域 & \begin{tabular}{|l|} 
住宅戸数密度、耐用年限、木 \\
造集合住宅率、老朽住宅戸数 \\
密度
\end{tabular} & $\begin{array}{l}\text { 十分な地区公共施設又は生活環境施設がないこと等によ } \\
\text { り住器境が劣っていると認められる }\end{array}$ \\
\hline & & & 住工混在型地区 & |三大都市圈における近郊整備地帯・都市開発区域 & $\begin{array}{l}\text { 住宅戸数密度、耐用年限、木 } \\
\text { 造集合住宅率、老朽住宅戸数 } \\
\text { 密度、工場密度 }\end{array}$ & $\begin{array}{l}\text { 十分な地区公共施設又は生活環境施設がないこと等によ } \\
\text { り住器境が少っていると認められるる }\end{array}$ \\
\hline & & \multicolumn{2}{|c|}{ 住宅市街地総合整備事業 } & 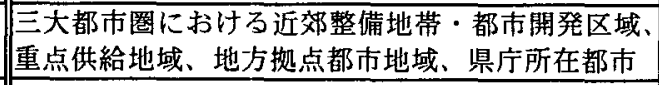 & $\begin{array}{l}\text { 人口25万以上の都市の通勤 } \\
\text { 圈、人口減少の都心地域 }\end{array}$ & 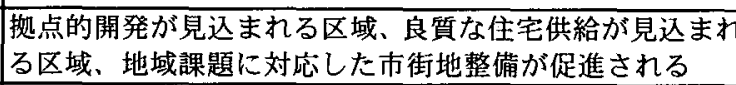 \\
\hline & \multirow{3}{*}{\begin{tabular}{|c|c|} 
建 \\
笏 \\
\end{tabular}} & \multicolumn{2}{|c|}{$\begin{array}{l}\text { 種市街地再開發事業 } \\
\text { (地方公共団体施行) }\end{array}$} & 市街化区域、都市計画決定した街路、高度利用地区 & 恧火建筑物の割合 & $\begin{array}{l}\text { 十分な公共施設がない、士地利用の状況が著しく不健全、 } \\
\text { 土地の高度利用化が都市機能の更新に貢献 }\end{array}$ \\
\hline & & \multirow{2}{*}{$\begin{array}{l}\text { 晏良建筑物等 } \\
\text { 備事業 }\end{array}$} & 優良再開発型 & 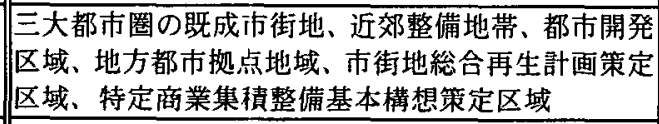 & 人口5万人以上の市の区域 & \\
\hline & & & 市街地住宅共給型 & 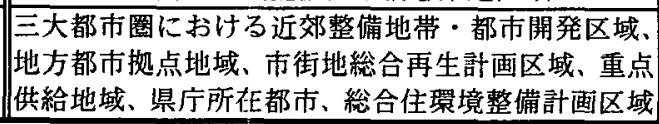 & $\begin{array}{l}\text { 通勤圈内人口が25万人以上の } \\
\text { 都市の区域 }\end{array}$ & \\
\hline
\end{tabular}




\section{表 2 適地選定上で必要となる基礎データの分類}

（a）前提となる規制・計画

国土開発に関する計画

\begin{tabular}{|c|c|}
\hline \multicolumn{2}{|c|}{ 都市の集中の進む大都市圏を対象に策定される計画 } \\
\hline 首都圈整備法 & 既成市街地、近郊整備地带、都市開発区域 \\
\hline 近畿圈整備法 & 既成都市区域、近刘整備区域、都市開発区域 \\
\hline 中部圏開発整備法 & 都市整備区域、都市開発区域 \\
\hline
\end{tabular}

特定の地域を対象に、特定の政策目標を達成するために策定される計画

\begin{tabular}{|l|l|}
\hline 大都市法 & 重点供給地域 \\
\hline
\end{tabular}

\begin{tabular}{|l|l}
\hline 地方拋点都市整備法 & 地方拠点都市地域 \\
\hline
\end{tabular}

特定商業集積法

大規模地震対策特別措置法 地霞防多対策強化地域

地震予知連絡会が指定する地域

土地利用に関する計画

都市地域における土地利用計画

\begin{tabular}{|c|c|}
\hline \multicolumn{2}{|l|}{ 都市計画法 } \\
\hline \multirow[t]{3}{*}{ マスタープラン } & 都市計画区域の指定 \\
\hline & 区域区分（線引き：市街化区域、調整区域） \\
\hline & 区域区分（整開保：市街地再開発方針の \\
\hline \multirow{4}{*}{ 地域地区 } & 随火地域 \\
\hline & 高度利用地区 \\
\hline & 建筑物の高さの最低限度を $7 \mathrm{~m}$ 以上とする \\
\hline & 旨定めた高度地区 \\
\hline 都市施設 & 都市計画道路 \\
\hline 市街地開発事業 & 土地区画整理事業 \\
\hline 地区計画 & 地区計画 \\
\hline 被災市街地復興特別措置法 & 被災市街地復興推進地域 \\
\hline \multicolumn{2}{|l|}{ 設省による事業制度 } \\
\hline 市街地総合再生事業制度要網 & 市街地総合再生計画策定区域 \\
\hline 総合住環境整備事業制度要綱 & 総合住環境整備計画区域 \\
\hline \multicolumn{2}{|c|}{ 方公共団体が制定した条例及び計面 } \\
\hline \multicolumn{2}{|c|}{ 地方自治法に即し都道府県が制定 県庁所在都市 } \\
\hline 建築基筆法に即し市町村が制定 & \begin{tabular}{|l} 
建筑物を 2 階建て以上の耐火建築物とする \\
定めた建筇協定
\end{tabular} \\
\hline 神戸市が制定した条例 & 災害復興促進区域 \\
\hline 地方自治体による復興計画 & 震災復興事業との整合 \\
\hline
\end{tabular}

(b) 地区現汾(数值)

\begin{tabular}{|l|l|}
\hline 人口 & $\begin{array}{l}\text { 人口25万人以上の都市の通勤圈、人口堿少の都心地域、人口 } 5 \text { 万人以上の } \\
\text { 市の区域、通勤圈内人众25万人上都市の区域 }\end{array}$ \\
\hline & $\begin{array}{l}\text { 而用年年限、耐火建築物物の割合、木造集合住宅率、住宅戸数密度、老朽住宅 } \\
\text { 户数密度、工場密度 }\end{array}$ \\
\hline
\end{tabular}

(c) 地区現況 (文言)

\begin{tabular}{|c|c|c|}
\hline \multirow[t]{15}{*}{ 平常時 } & 地区現況 & $\begin{array}{l}\text { 十分な地区公共施設又は生活環境施設がないこと等により住環 } \\
\text { 境が劣っていると認められる䧕 } \\
\text { 十分な公共施設がない } \\
\text { 土地利用の状況が著しく不健全 }\end{array}$ \\
\hline & \multirow[t]{8}{*}{ 政策判断 } & 公共施設の整備改善を必要とする区域 \\
\hline & & 宅地の利用增進を必要とする区域 \\
\hline & & 交通の隘路打開が必要な区域 \\
\hline & & 土地の高度利用が必要な区域 \\
\hline & & 重要な公共施設の新設又は改筑に伴う市街地整備が必要な区域 \\
\hline & & 急速な市街化に伴う緊急整備が必要な区域 \\
\hline & & 大量な宅地整備に伴う緊急整備が必要な区域 \\
\hline & & $\begin{array}{l}\text { 地域防災計画に定められた避難地・避難路・延焼遮断帯の周辺 } \\
\text { 区域又は避難地の区域のうちで不燃化促進を図る必要がある }\end{array}$ \\
\hline & \multirow[t]{6}{*}{ 将来像 } & 概ね 210 年以内に区域内のほぼ70\%以上の部分に耐灭建築物が建 \\
\hline & & 築されることが確実であると認められる区域 \\
\hline & & 撄点的開発が見込まれる区域 \\
\hline & & 良質な住宅供給が見込まれる \\
\hline & & 地域課題に対応した市街地整備が促進される \\
\hline & & 土地の高度利用化が都市機能の更新に貢献 \\
\hline \multirow[t]{5}{*}{ 災害時 } & 地区現況 & 相当数の建筑物が堿失 \\
\hline & \multirow[t]{3}{*}{ 政策判断 } & 良好な市街地への再生が必要な地区 \\
\hline & & 土地区画整理事業・市街地再開発事業等を実施する必要がある \\
\hline & & 災害復興に伴う緊急整備が必要な区域 \\
\hline & 将来像 & 不良な街区垻境が形成されるおそれがある \\
\hline
\end{tabular}


以降、「要領」で掲げられた調查項目を市街地復興 都市計画を検討する際に利用可能な基礎テータとし て、前章で得られた必要となる基礎データとの比較 を行う。

\section{2. 必要となるデータと利用可能なデータの比較} まず、「前提となる規制・計画」について見てみる と、「要領」においては「4.土地利用及び土地利用条 件」の中に「法適用状況」という中項目があり、「土地 利用関連諸制度の適用状況を把握し、土地利用計画 策定の基礎資料とする」という目的が述べられ、関 連制度を地図上に整理するように求めている。した がって、このデータをGIS上で利用するのは比較的 容易であると考えられる。

「地区の現況」を見てみるよ、「数值指標によって 評価しうるもの」の内、災害発生後にデータ収集を 行う「被災状況」を除き、「人口」、「建築物」に関する 基礎データは概ね「要領」の調查項目として掲げられ ている。しかし、「木造集合住宅率」を例に挙げる と、「建物用途別現況図」から「共同住宅」、「店舗併 用共同住宅」、「作業所併用共同住宅」に該当する建 筑物を抽出し、「建物構造別・階数別現況図」から抽 出された「木造」に該当する建築物と重ねあわせなけ れば、「木造集合住宅」を得ることができない。すな わち、「要領」で示された調查項目から直接得ること ができない必要データがある。この場合、現状で は、手作業で「建物用途別現況図」から特定の用途の みを抜き出した主題図と、同じく手作業で「建物構 造別・階数別現況図」から「木造」の建築物のみを抜 き出した主題図を見比べる以外に方法が無いが、 GISを導入することによって、建築物の属性として 用途と構造を同時に管理することが可能となり、作 業効率の大きな向上が期待できる。

「文言によって記述されているもの」について は、前章でも指摘したように、条件として述べられ ている内容が抽象的であり、現状ではGISによる定 量的な処理になじみにくいと考えられる。しかし、 都市計画に関連する規制、事業の策定に当たって は、地権者など、関係する多数の主体間での検討・ 調整が必要であることから、適地選定に至る判断過
程の正当性が可能な限り客観的に保証されることが 望ましい。したがって、今後、「十分な」という表現 を数量に換算する試みなどが要求されるであろう。 また、政策判断によって「公共施設の整備改善を必 要とする区域」などとされた場合には、その情報を 公開し、広く検討する機会を設けることが求められ ると考えられる。このような状況でもGISの活用が 大いに期待される。

「被災状況」については、平常時に定期的に実施 される都市計画基礎調查の中で調查されうるもので はないが、GPS（Global Positioning System）と携帯 型コンピュータを組み合わせ、GISを被災状況を調 査する現場に持ち込むことによって、デー夕収集を 効率的に行う試みが既に始まっている（糸井川ほ か，1996；碓井ほか，1996）。これは災害時に留ま らず、都市計画基礎調查における建物用途現況調査 などの平常時における現地調査にも活用されるもの であり、今後の進展が期待される。

これらの状況を踏まえると、大規模災害後の市街 地復興計画を策定する際に、データウェアハウスと して地方公共団体が有効に機能するための基本的な データは、概ね収集されているといえる。しかしな がら、実際の作業にそれらのデータを十分に活用で きる状況にあるとは言い難く、GISの導入を始めと する課題が残されており、検討の余地が大きい。ま た、GIS導入後も、データ活用のノウハウそのもの については、これからの蓄積を待つ必要がある。

\section{5. まとめと課題}

市街地復興都市計画にかかる適地選定に必要な データと都市計画基礎調查を通じて入手が可能な データの比較を通じて以下の事が明らかとなった。

（1）地方公共団体においてGISが活用されるため には、データウェアハウスとしての機能が備わつ ていく必要があること。

（2）復興計画にかかる規制・事業のヒエラルキー に応じて規制・事業のデータを作成することによ り、単一の規制・事業に留まらない効率化が期待 できること。

（3）地方公共団体は、現在、市街地復興都市計画 
のためのデータウェアハウスとして必要なデータ

を所有しているが、十分に活用できる環境に無い

こと。

今後の課題としては、以下の様な項目が挙げられ

る。「要領」はあくまで標準的な調査内容について述 ベられたものであるため、それぞれの状況に応じて 項目の取捨選択が行なわれており、必ずしも実態を 反映していない。したがって、地方公共団体のデー 夕整備の現状については更に研究を進める必要があ る。また「要綱」は昭和62年に作成されているため、 その後の電算技術、特にGIS関連技術の進展を内容 に反映させることが望ましい。今後、そのための具 体的提案の内容について検討を進めて行きたい。

\section{謝辞}

本研究に対して、岡部篤行教授（東京大学）、大 村謙二郎教授（筑波大学）、竹内佑一氏（計量計画 研究所）より、貴重な示唆と助言をいただいた。こ こに記して謝辞としたい。

注）

1) 例えば、 http://www.gsi-mc.go.jp/JIS/GIS/GIS-kenk.htmlを 参照されたい。

2) 例えば、

http://www.gsi-mc.go.jp/ISO/JIS/isomain.htmlを 参照されたい。

\section{参考文献}

糸井川栄一・岩田司・寺木彰浩（1996）兵庫県南部 地震における建築物被災情報等のGIS化の問題 点之電子野帳の開発、「地域安全学会論文報告 集小、6、269-277.

岩井哲・亀田弘行・碓井照子・盛川仁（1996） 1995 年兵庫県南部地震による西宮市の都市施設被害 のGISデータベース化と多重分析、「GIS-理論と 応用小、4(2)、63-73.

碓井照子・橋本潤治（1996）電子地図とGPS搭載の 携帯型パソコンGISの開発-地域現場からの緊急 情報取得システムへの応用-、「地理情報システ 厶学会論文講演集」、5、39-42

田中公雄・今井修・寺木彰浩(1995)自治体における
GIS取り組み動向、「GIS-理論と応用」、3(1)、 61-68.

玉川英則編(1996)『都市をとらえる-地理情報システ ム（GIS）の現在と未来-』、東京都立大学都市 研究所.

寺木彰浩 - 岩田司 - 糸井川栄一 - 脇山芳和 - 石坂公 二・長島雅則・白尾克伸・小原保子(1995)兵庫 県南部地震の被災地域における復興都市計画支 援情報システムの検討、「GIS-理論と応用」、3 (2)、1-8.

山崎文雄（1996）地理情報システムの都市防災への 応用、「GIS-理論と応用」、4(1)、61-68. 